\title{
AUTOMATIC LANDING AND WAYPOINT SYSTEM BERBASIS KOMBINASI GPS DAN MESIN VISI UNTUK ULTIROTOR PADA KONTES ROBOT TERBANG INDONESIA DIVISI VERTICAL TAKE OFF LANDING
}

\author{
Arsyad Cahya Subrata \\ Program Studi Teknik Elektro Universitas Ahmad Dahlan Yogyakarta \\ Jln. Prof.Dr. Supomo Yogyakarta. TIp. 0274-379418, Fax. 0274-381523 \\ email: arsyadcahya@gmail.com
}

\begin{abstract}
Quadcopter is one of the multi motor types (flying robot) that uses four motors as the main driver. In 2015, Ahmad Dahlan University participated in contest of ROBOT TERBANG INDONESIA in the division of Vertical Take Off Landing. In this contest, the mission of the robot is to turn off the fire placed on top of a halogen lamp which was lit in a certain arena as a full autonomous using one activation button of the remote control. The robot was using GPS when doing the waypoint navigation and landing, as a result, the robot position while navigating was approaching the fires and it was misslanding or hade a few centimeters from the target point due to the tolerance range of the GPS itself. This mission is carried out with a vision system in which the image is taken of halogen light and a landmark home to reduce the use of GPS in full. The image processing was done by Odroid-XU3 as a companion computer and the movements of the robot navigation was done by Pixhawk as a flight controller. The Command of Odroid-XU3 sent serially via telemetry pin 2 on the Pixhawk. This test was conducted to determine the comparative results of fully GPS-based navigation with a combination of GPS-based navigation and vision machine. According to the research, the robot successfully did the mission well and it reduced dependency of GPS with a vision system. From the results of durability testing in the error detection of halogen light and detection of landmark home in indoor by giving the other resemble objects, the endurance of objects fault detection is $100 \%$, except when it was detecting a landmark home with a distraction of brown square, the durability in error detection is $80 \%$. Based on the the testing results of navigation of the robot doing the mission of approaching the halogen light and landing to the home, it can be concluded that the average distance of the robot approaching GPS-based halogen lamps from the midpoint of media measurement is 86.5 $\mathrm{cm}$, while the average distance of the robot with a GPS-based and vision machine in the third time of the test is $30923 \mathrm{~cm}$. The percentage of the successful of the robot landing to can land to the Homebased GPS is $10 \%$, while the percentage of successful robot with by GPS-based and vision machine on the third time of the test is $70 \%$. Results obtained from the movement of the robot with a combination of GPS-based systems and machine vision to approach the halogen light and do a landing zone in the landmark home is a robot able to navigate more accurately compared to robot navigation using GPS guidance in full.
\end{abstract}

Keywords : quadcopter; pixhawk; odroid-XU3; image processing

\begin{abstract}
Abstrak
Quadcopter adalah salah satu tipe multimotor (robot terbang) yang menggunakan 4 buah motor sebagai penggerak utamanya. Pada tahun 2015, Universitas Ahmad Dahlan mengikuti Kontes Robot Terbang Indonesia divisi Vertical Take Off Landing. Dalam lomba ini robot melaksanakan misi memadamkan api yang diletakkan di atas lampu halogen yang dinyalakan pada arena tertentu secara full autonomous menggunakan aktifasi 1 tombol dari remot kontrol. Karena robot menggunakan GPS pada saat melakukan navigasi waypoint dan landing, maka posisi robot saat bernavigasi mendekati titik api dan landing tidak tepat atau melenceng beberapa sentimeter dari titik yang dituju disebabkan toleransi jarak yang dimiliki oleh GPS itu sendiri. Misi ini dilakukan dengan sistem visi yang mana citra diambil dari cahaya lampu halogen dan landmark home untuk mengurangi penggunaan GPS secara penuh. Pemrosesan citra tersebut dilakukan oleh Odroid-XU3 sebagai companion computer dan pergerakan navigasi robot dilakukan oleh Pixhawk sebagai flight controller. Perintah dari Odroid-XU3 dikirim secara serial melalui pin telemetry 2 yang terdapat pada Pixhawk. Pengujian ini dilakukan untuk mengetahui hasil perbandingan navigasi berbasis GPS
\end{abstract}

Automatic Landing and Waypoint System Berbasis Kombinasi GPS dan Mesin Visi untuk Multirotor pada Kontes Terbang Indonesia Divisi Vertical Take Off Landing (M.Ramadhani) 
secara penuh dengan navigasi berbasis kombinasi GPS dan mesin visi. Dari hasil pengujian ketahanan dalam kesalahan deteksi cahaya lampu halogen dan deteksi landmark home secara indoor dengan memberi objek lain yang menyerupai, ketahanan dalam kesalahan deteksi objek adalah $100 \%$, kecuali saat mendeteksi landmark home dengan objek gangguan persegi warna coklat ketahanan dalam kesalahan deteksi yaitu sebesar $80 \%$. Dari hasil pengujian navigasi robot melaksanakan misi mendekati cahaya lampu halogen dan landing ke home dapat disimpulkan bahwa rata-rata jarak robot mendekati lampu halogen berbasis GPS dari titik tengah media ukur adalah 86.5 $\mathrm{cm}$, sedangkan rata-rata jarak robot dengan berbasis kombinasi GPS dan mesin visi pada ketiga waktu pengujian adalah $30.923 \mathrm{~cm}$. Dan persentase keberhasilan robot dapat landing ke Home berbasis GPS adalah 10\%, sedangkan persentase keberhasilan robot dengan berbasis kombinasi GPS dan mesin visi pada ketiga waktu pengujian adalah $70 \%$. Hasil yang didapatkan dari pergerakan robot dengan sistem berbasis kombinasi GPS dan mesin visi untuk mendekati cahaya lampu halogen dan melakukan landing di dalam zona landmark home adalah robot dapat bernavigasi lebih akurat dibandingkan dengan navigasi robot menggunakan panduan GPS secara penuh.

Kata kunci : Quadcopter; pixhawk; odroid-XU3; pengolahan citra

\section{Pendahuluan}

Kontes Robot Terbang Indonesia (KRTI) merupakan salah satu kontes robot tingkat nasional yang diadakan oleh Direktorat Jendral Pendidikan Tinggi (DIKTI) secara rutin tiap tahunnya. Kontes Robot Terbang Indonesia ini memiliki beberapa divisi salah satunya yaitu Vertical Take Off Landing (VTOL) dengan misi memadamkan titik api yang berada pada suatu arena. Titik api tersebut sudah diletakkan sedemikian rupa dan akan dinyalakan secara acak ketika robot sudah siap. Robot yang digunakan dalam perlombaan ini yaitu berbentuk multirotor (robot terbang yang memiliki beberapa motor sebagai penggerak utama agar dapat terbang). Robot melakukan misi dengan cara full autonomus, yaitu robot secara otomatis melaksanakan misi tanpa pengendalian langsung melalui remot kontrol, melainkan dengan menekan 1 tombol dan membiarkan robot terbang secara otomatis. Misi yang dilakukan yaitu robot melakukan takeoff dari home kemudian melakukan pencarian titik api dan mendekati titik tersebut untuk memadamkannya, selanjutnya robot terbang dan melakukan landing di Home [10].

Masalah yang sering dihadapi dalam KRTI divisi VTOL ini adalah menentukan titik api yang tepat dan akurat. Untuk memudahkan wahana mendeteksi titik api maka diberi lampu halogen pada setiap titiknya, sehingga cahaya dari lampu halogen tersebut dapat dideteksi menggunakan kamera maupun sensor lainnya. Selama ini kebanyakan robot KRTI khususnya divisi VTOL selalu mengandalkan sistem Waypoint dengan GPS yang memiliki toleransi sejauh 0.9 meter dari titik sebenarnya. Karena toleransi jarak yang disediakan oleh GPS tersebut adalah 0.9 meter [11]. Oleh karena itu, dibutuhkan suatu sistem kontrol untuk menunjang robot agar dapat mengatasi kelemahan dalam pola Waypoint yang digunakan untuk mendekati titik api di dalam arena pertandingan.

Dalam penelitian ini, akan dirancang suatu sistem penerbangan robot KRTI divisi VTOL dengan menggunakan kombinasi GPS dan mesin visi. Sistem tersebut dirancang supaya robot melakukan misi dengan mengurangi penggunaan GPS secara penuh pada saat mendekati titik api dan melakukan landing.

\section{Metode Penelitian}

\subsection{Bahan yang digunakan}

1) Pixhawk sebagai Flight Controller digunakan untuk kontroler utama robot.

2) Odroid-XU3 berbasis Linux digunakan sebagai Companion Computer sebagai penerima citra yang ditangkap dari webcam dan diolah dengan teknik pengolahan citra menggunakan library OpenCV.

3) Webcam Logitech C905 digunakan sebagai sensor untuk mengambil citra yang akan diproses oleh Odroid-XU3.

4) USB to TTL CP2102 digunakan untuk memghubungkan dan mengirimkan instruksi dari OdroidXU3 melalui USB ke Pixhawk melalui pin telemetry 2.

5) GPS Ublox-7M digunakan untuk menentukan titik koordinat dari lampu halogen dan landmark home yang akan dideteksi.

6) Catu Daya berupa Battery Litium Polimer (Li-po) sebesar 11,1 Volt/5300mAh.

7) Motor Brushless digunakan sebagai penggerak utama robot berjumlah 4 buah masing-masing sebesar 800KV. 
8) ESC digunakan sebagai pengendali putaran motor Brushless berjumlah 4 buah masing-masing memiliki kapasitas sebesar 40A.

9) Ubec 5V 5A digunakan untuk menurunkan tegangan dari catu daya ke Odroid-XU3.

\subsection{Alat Penelitian}

1) PC/Laptop dengan spesifikasi Prosesor Core i3 $2310 \mathrm{M} @ 1,90 \mathrm{GHz}, \mathrm{RAM} 2 \mathrm{~GB}$, dan OS Windows 7 64bit.

2) Software Mission Planner digunakan untuk melakukan kalibrasi utama pada robot.

3) Software Ultra VNC Viewer digubakan untuk menampilkan tampilan dari Odroid-XU3 ke layar laptop.

4) Aplikasi DroneKit-Python digunakan sebagai modul pada Odroid-XU3 diprogram untuk misi autopilot yang dieksekusi oleh Pixhawk.

5) Operating System LinuX jenis Ubuntu sebagai sistem operasi dari Odroid-XU3.

6) Library OpenCV digunakan sebagai pengolahan citra digital.

7) Kabel LAN.

8) Laser mainan.

9) LUX meter

\subsection{Diagram Sistem}

Konstruksi robot yang digunakan adalah tipe Quadcopter (menggunakan 4 buah motor sebagai penggerak utamanya) dengan Pixhawk sebagai Flight Controller. Battery 12 volt digunakan untuk men-supply tegangan ke Pixhawk dan ke Odroid-XU3 melalui Ubec 5V 5A. Kamera Webcam terhubung dengan Odroid-XU3. Sedangkan motor brushless terhubung dengan Pixhawk yang sebelumnya dihubungkan dengan ESC terlebih dahulu. USB to Serial digunakan untuk komunikasi antara Pixhawk dengan Odroid-XU3.

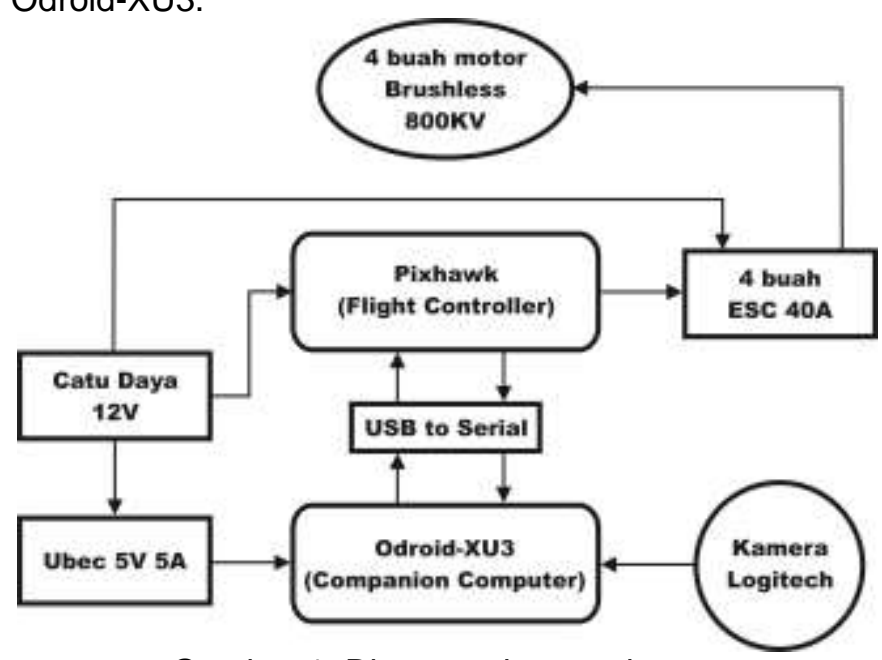

Gambar 1. Diagram sistem robot

\subsection{Prinsip Kerja Sistem Navigasi Robot}

Pada pelaksanaan misi ini robot akan melakukan navigasi pencarian titik api kemudian mendekati dan menahan beberapa detik diatas lampu halogen. Selanjutnya robot akan kembali ke posisi Home dengan mendeteksi landmark Home dan melakukan landing. Take Off robot dilakukan dengan cara menekan 1 tombol pada remot kontrol dan mempertahankan posisi terbang ketika ketinggiannya sudah terpenuhi. Selanjutnya robot akan menuju ke koordinat lampu halogen. Kemudian kamera akan mendeteksi cahaya dari lampu halogen yang dianggap sebagai titik api. Robot terbang kearah titik yang terdeteksi kemudian terbang merendah mendekati titik tersebut. Ketika ketinggian robot sudah tercukupi, robot akan mempertahankan ketinggian sekitar 1 meter tersebut selama 5 detik.. Apabila titik sudah tidak terdeteksi, maka robot akan terbang pada ketinggian 3 meter dan menuju ke koordinat Home. Selanjutnya robot akan mendeteksi pola Home yang akan dituju, kemudian robot mendarat secara otomatis. 


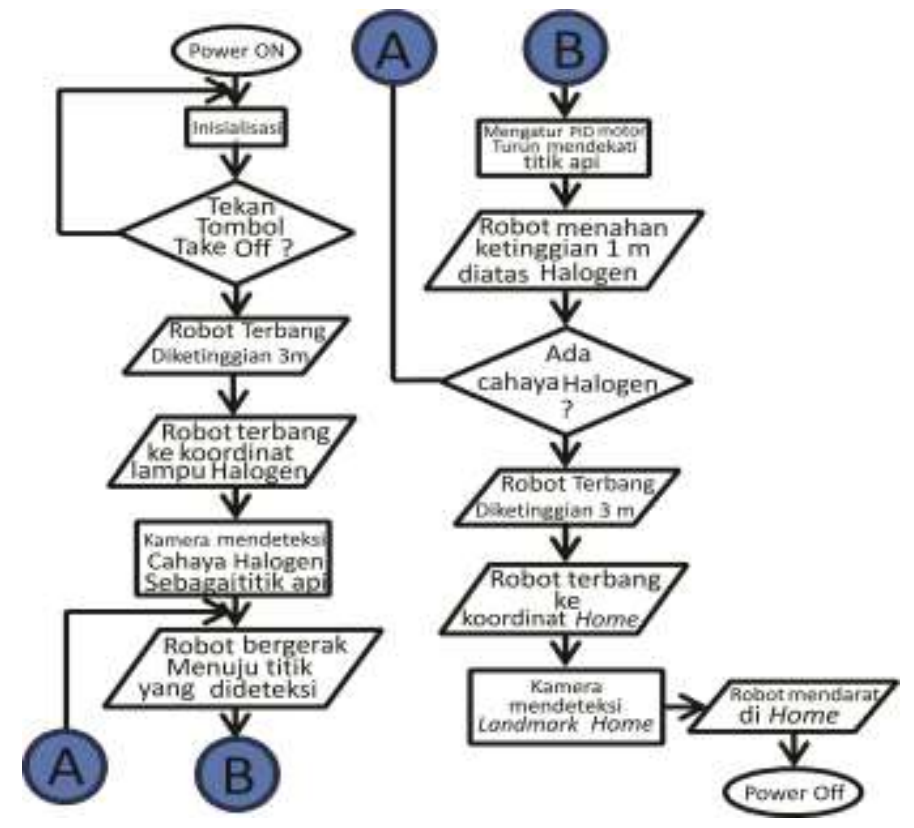

Gambar 2. Diagram alir sistem navigasi robot

\section{Hasil Dan Pembahasan}

\subsection{Pengujian Mesin Visi}

Pengujian deteksi mesin visi ini dilakukan secara indoor. Pada tahap ini dilakukan pengujian terhadap sistem visi agar dapat mendeteksi cahaya lampu halogen dan landmark home dengan baik. Pengujian ini dilakukan untuk mengetahui apakah sistem visi yang digunakan telah dapat bekerja dengan maksimal.

\subsubsection{Pengujian deteksi cahaya lampu Halogen}

Pengujian deteksi cahaya lampu halogen ini dilakukan secara indoor. Pada pengujian ini diberikan objek yang menyerupai bentuk cahaya lampu halogen yang dideteksi oleh kamera. Objek menyerupai bentuk cahaya lampu halogen yang digunakan yaitu lingkaran dengan warna merah, hitam, dan biru. Hasil pengujian deteksi cahaya lamou halogen ditunjukkan pada Tabel 1 berikut.

Tabel 1. Pengujian deteksi cahaya lampu halogen

\begin{tabular}{cccc}
\hline Uji Ke- & $\begin{array}{c}\text { Objek lingkaran } \\
\text { warna merah }\end{array}$ & $\begin{array}{c}\text { Objek lingkaran } \\
\text { warna hitam }\end{array}$ & $\begin{array}{c}\text { Objek lingkaran } \\
\text { warna biru }\end{array}$ \\
\hline 1 & $\mathrm{X}$ & $\mathrm{X}$ & $\mathrm{X}$ \\
\hline 2 & $\mathrm{X}$ & $\mathrm{X}$ & $\mathrm{X}$ \\
\hline 3 & $\mathrm{X}$ & $\mathrm{X}$ & $\mathrm{X}$ \\
\hline 4 & $\mathrm{X}$ & $\mathrm{X}$ & $\mathrm{X}$ \\
\hline 5 & $\mathrm{X}$ & $\mathrm{X}$ & $\mathrm{X}$ \\
\hline 6 & $\mathrm{X}$ & $\mathrm{X}$ & $\mathrm{X}$ \\
\hline 7 & $\mathrm{X}$ & $\mathrm{X}$ & $\mathrm{X}$ \\
\hline 8 & $\mathrm{X}$ & $\mathrm{X}$ & $\mathrm{X}$ \\
\hline 9 & $\mathrm{X}$ & $\mathrm{X}$ & $\mathrm{X}$ \\
\hline 10 & $\mathrm{X}$ & $\mathrm{X}$ & $\mathrm{X}$ \\
\hline
\end{tabular}

Persentase kesalahan terdeteksinya objek lingkaran warna merah dengan cahaya lampu halogen adalah :

$$
\begin{gathered}
\text { Persentase kesalahan }=\frac{\text { Lingkaran warna merah terdeteksi }}{\text { Jumlah pengujian }} X 100 \% \\
=\frac{0}{10} X 100 \%=0 \%
\end{gathered}
$$


Persentase kesalahan terdeteksinya objek lingkaran warna hitam dengan cahaya lampu halogen adalah :

$$
\begin{gathered}
\text { Persentase kesalahan }=\frac{\text { Lingkaran warna hitam terdeteksi }}{\text { Jumlah pengujian }} X 100 \% \\
=\frac{0}{10} X 100 \%=0 \%
\end{gathered}
$$
adalah :

Persentase kesalahan terdeteksinya objek lingkaran warna biru dengan cahaya lampu halogen

$$
\begin{gathered}
\text { Persentase kesalahan }=\frac{\text { Lingkaran warna biru terdeteksi }}{\text { Jumlah pengujian }} X 100 \% \\
=\frac{0}{10} X 100 \%=0 \%
\end{gathered}
$$

Jadi persentase kesalahan terdeteksinya cahaya lampu halogen dengan objek lingkaran warna merah, hitam dan biru terhadap pengujian mesin visi adalah $0 \%$.

Berdasarkan persentase kesalahan terdeteksinya cahya lampu halogen dengan objek lingkaran dalam beberapa warna tersebut dapat disimpulkan semakin kecil nilai persentase kesalahan maka semakin baik deteksi cahaya lampu halogen, karena semakin kecil nilai persentase kesalahan deteksi maka semakin besar keakuratan deteksi cahaya lampu halogen.

\subsubsection{Pengujian deteksi landmark home}

Pengujian deteksi landmark home ini dilakukan secara indoor. Pada pengujian ini diberikan objek yang menyerupai bentuk landmark home yang dideteksi oleh kamera. Objek menyerupai bentuk landmark home yang digunakan yaitu persegi dengan warna merah, cokelat, dan biru. Hasil pengujian deteksi cahaya lamou halogen ditunjukkan pada Tabel 2 berikut.

Tabel 2. Pengujian deteksi landmark home

\begin{tabular}{cccc}
\hline Uji Ke- & $\begin{array}{c}\text { Objek persegi } \\
\text { warna merah }\end{array}$ & $\begin{array}{c}\text { Objek persegi } \\
\text { warna coklat }\end{array}$ & $\begin{array}{c}\text { Objek persegi } \\
\text { warna biru }\end{array}$ \\
\hline 1 & $\mathrm{X}$ & $\mathrm{X}$ & $\mathrm{X}$ \\
\hline 2 & $\mathrm{X}$ & $\mathrm{X}$ & $\mathrm{X}$ \\
\hline 3 & $\mathrm{X}$ & $\mathrm{X}$ & $\mathrm{X}$ \\
\hline 4 & $\mathrm{X}$ & $\sqrt{ }$ & $\mathrm{X}$ \\
\hline 5 & $\mathrm{X}$ & $\mathrm{X}$ & $\mathrm{X}$ \\
\hline 6 & $\mathrm{X}$ & $\mathrm{X}$ & $\mathrm{X}$ \\
\hline 7 & $\mathrm{X}$ & $\mathrm{X}$ & $\mathrm{X}$ \\
\hline 8 & $\mathrm{X}$ & $\mathrm{X}$ & $\mathrm{X}$ \\
\hline 9 & $\mathrm{X}$ & $\sqrt{ }$ \\
\hline 10 & $\mathrm{X}$ & $\mathrm{X}$ & $\mathrm{X}$ \\
\hline
\end{tabular}

Persentase kesalahan terdeteksinya objek persegi warna merah dengan landmark home adalah :

$$
\begin{gathered}
\text { Persentase kesalahan }=\frac{\text { Persegi warna merah terdeteksi }}{\text { Jumlah pengujian }} X 100 \% \\
=\frac{0}{10} X 100 \%=0 \%
\end{gathered}
$$

Persentase kesalahan terdeteksinya objek persegi warna coklat dengan landmark home adalah :

$$
\begin{gathered}
\text { Persentase kesalahan }=\frac{\text { Persegi warna coklat terdeteksi }}{\text { Jumlah pengujian }} \times 100 \% \\
=\frac{2}{10} X 100 \%=20 \%
\end{gathered}
$$

Persentase kesalahan terdeteksinya objek persegi warna biru dengan landmark home adalah :

$$
\text { Persentase kesalahon }=\frac{\text { Persegi warna biru terdeteksi }}{\text { Jumlah pengujian }} X 100 \%
$$




$$
=\frac{0}{10} X 100 \%=0 \%
$$

Jadi persentase kesalahan terdeteksinya landmark home dengan objek persegi warna merah dan biru terhadap pengujian mesin visi adalah $0 \%$. Sedangkan kesalahan terdeteksinya landmark home dengan objek persegi warna coklat adalah $20 \%$

Berdasarkan persentase kesalahan terdeteksinya landmark home dengan objek persegi dalam beberapa warna tersebut dapat disimpulkan semakin kecil nilai persentase kesalahan maka semakin baik deteksi landmark home, karena semakin kecil nilai persentase kesalahan deteksi maka semakin akurat deteksi landmark home.

\subsection{Pengujian Sistem Navigasi}

Pengujian ini dilakukan dengan 2 cara yaitu menggunakan full GPS dan menggunakan sistem mesin visi dengan bantuan GPS untuk mendekati titik koordinat objek deteksi. Hal ini dilakukan untuk melihat perbedaan hasil yang akan diperoleh sehingga dapat dibandingkan sistem mana yang lebih akurat saat mendekati objek deteksi.

\subsubsection{Pengujian Sistem Navigasi Berbasis Full GPS}

Pengujian sistem navigasi ini dilakukan dengan menggunakan full GPS untuk bernavigasi menuju titik koordinat halogen dan bernavigasi mendekati titik halogen serta bernavigasi menuju titik home dan bernavigasi landing ke home. Pada pengujian ini tidak perlu dilakukan dalam tiga waktu yang berbeda yaitu pagi hari, siang hari dan sore hari karena penggunaan GPS tidak berpengaruh pada perbedaan cahaya matahari.

\subsubsection{Pengujian Mendekati Cahaya Lampu Halogen}

Pengujian ini dilakukan untuk mengetahui jarak robot ketika bernavigasi mendekati titik halogen dengan full GPS autonomus. Jarak diukur dari robot dengan titik tengah lampu halogen. Hasil pengujian sisem navigasi berbasis full GPS untuk mendekati cahaya lampu halogen dapat dilihat pada Table 3.

Tabel 3. Pengujian mendekati cahaya lampu halogen (full GPS)

\begin{tabular}{cc}
\hline Uji Ke- & Jarak dengan titik tengah Halogen \\
\hline 1 & $70 \mathrm{~cm}$ \\
\hline 2 & $80 \mathrm{~cm}$ \\
\hline 3 & $75 \mathrm{~cm}$ \\
\hline 4 & $110 \mathrm{~cm}$ \\
\hline 5 & $95 \mathrm{~cm}$ \\
\hline 6 & $90 \mathrm{~cm}$ \\
\hline 7 & $90 \mathrm{~cm}$ \\
\hline 8 & $80 \mathrm{~cm}$ \\
\hline 9 & $90 \mathrm{~cm}$ \\
\hline 10 & $85 \mathrm{~cm}$ \\
\hline Total jarak & $865 \mathrm{~cm}$ \\
\hline
\end{tabular}

Rata-rata jarak robot mendekat ke halogen dengan titik tengah adalah :

$$
\begin{gathered}
\text { Rata }- \text { rata jarak }=\frac{\text { Total jarak }}{\text { jumlah heberhasilan robot mendekat he halogen }} \\
=\frac{865 \mathrm{~cm}}{10}=86.5 \mathrm{~cm}
\end{gathered}
$$
$86.5 \mathrm{~cm}$.

Jadi rata-rata jarak robot mendekati lampu halogen dengan titik tengah media ukur adalah

Berdasarkan berdasarkan nilai rata-rata jarak robot mendekati lampu halogen dengan titik tengah media ukur dapat disimpulkan bahwa semakin pendek jarak yang dihasilkan maka semakin akurat robot bernavigasi mendekati titik tengah lampu halogen. 


\subsubsection{Pengujian Landing ke Home}

Pengujian ini dilakukan untuk mengetahui jarak robot ketika bernavigasi landing ke home dengan full GPS autonomus. Pengujian dilihat dari keberhasilan robot dapat mendarat tepat di home. Hasil pengujian sisem navigasi berbasis full GPS untuk landing ke home dapat dilihat pada Tabel 4. berikut.

Tabel 4. Pengujian landing ke home (full GPS)

\begin{tabular}{cc}
\hline Uji Ke- & Landing ke Home \\
\hline 1 & $\mathrm{X}$ \\
\hline 2 & $\mathrm{X}$ \\
\hline 3 & $\sqrt{ }$ \\
\hline 4 & $\mathrm{X}$ \\
\hline 5 & $\mathrm{X}$ \\
\hline 6 & $\mathrm{X}$ \\
\hline 7 & $\mathrm{X}$ \\
\hline 8 & $\mathrm{X}$ \\
\hline 9 & $\mathrm{X}$ \\
\hline 10 & $\mathrm{X}$ \\
\hline
\end{tabular}

Persentase tingkat keberhasilan robot mendekat ke halogen adalah :

$$
\begin{aligned}
\text { Persentase keberhasilan }= & \frac{\text { Robot mendekat ke halogen }}{\text { jumlah pengujian }} X 100 \% \\
& =\frac{1}{10} X 100 \%=10 \%
\end{aligned}
$$

Jadi persentase keberhasilan robot dapat landing ke Home adalah 10\%. Berdasarkan persentase keberhasilan robot landing ke Home tersebut dapat disimpulkan bahwa semakin besar nilai prosentase keberhasilan yang didapat maka semakin baik robot dapat melaksanakan misi navigasi landing secara otomatis.

\subsubsection{Pengujian Sistem Navigasi Berbasis Mesin Visi}

Pengujian sistem navigasi ini dilakukan untuk mengetahui apakah robot dapat melaksanakan automatisasi gerakan mendekati objek yang dideteksi. Pengujian dilakukan dalam tiga waktu yang berbeda yaitu pada pagi hari, siang hari dan sore hari. Hal ini mengacu pada perlombaan KRTI 2015 yang mana peserta mendapat urutan terbang secara acak, yaitu di pagi, siang ataupun sore hari. Pengujian sistem navigasi ini meliputi uji navigasi ketika robot mendeteksi cahaya lampu halogen dan uji navigasi ketika robot mendeteksi landmark home.

\subsubsection{Pengujian Mendekati Cahaya Lampu Halogen}

Pengujian ini dilakukan menggunakan bantuan media ukur berdiameter 1 meter yang diletakkan di bawah lampu halogen. Pada media ukur tersebut diberi garis-garis lingkaran dengan jarak antara garis lingkaran satu dengan yang lainnya adalah $5 \mathrm{~cm}$. Sehingga media ukur tersebut memiliki jarak sebesar $5 \mathrm{~cm}$ untuk tiap jarak garis lingkaran dengan titik pusatnya.

\subsection{Pengujian Pagi Hari}

Pada pengujian ini terlebih dahulu diukur intensitas cahaya pada area sekitar lapngan pengujian. Hasil pengujian sistem navigasi berbasis mesin visi mendekati cahaya lampu halogen pada pagi hari dapat dilihat pada Tabel 5 berikut.

\begin{tabular}{|c|c|c|c|c|}
\hline Uji Ke- & $\begin{array}{l}\text { Intensitas } \\
\text { Cahaya }\end{array}$ & $\begin{array}{l}\text { Deteksi } \\
\text { Halogen }\end{array}$ & $\begin{array}{l}\text { Mendekat ke } \\
\text { Halogen }\end{array}$ & $\begin{array}{c}\text { Jarak dengan titik } \\
\text { tengah Halogen }\end{array}$ \\
\hline 1 & \multirow{9}{*}{$\begin{array}{l}\text { Rentang nilai } \\
\text { dari Lux meter : }\end{array}$} & $\sqrt{ }$ & $\sqrt{ }$ & $20 \mathrm{~cm}$ \\
\hline 2 & & $\sqrt{ }$ & $\sqrt{ }$ & $20 \mathrm{~cm}$ \\
\hline 3 & & $\sqrt{ }$ & $\sqrt{ }$ & $15 \mathrm{~cm}$ \\
\hline 4 & & $\sqrt{ }$ & $\sqrt{ }$ & $30 \mathrm{~cm}$ \\
\hline 5 & & $\sqrt{ }$ & $\sqrt{ }$ & $40 \mathrm{~cm}$ \\
\hline 6 & & $\sqrt{ }$ & $\sqrt{ }$ & $55 \mathrm{~cm}$ \\
\hline 7 & & $\sqrt{ }$ & $\mathrm{X}$ & - \\
\hline 8 & & $\sqrt{ }$ & $\sqrt{ }$ & $20 \mathrm{~cm}$ \\
\hline 9 & & $\sqrt{ }$ & $X$ & - \\
\hline
\end{tabular}

Tabel 5. Pengujian mendekati cahaya lampu halogen pada pagi hari

Automatic Landing and Waypoint System Berbasis Kombinasi GPS dan Mesin Visi untuk Multirotor pada Kontes Terbang Indonesia Divisi Vertical Take Off Landing (M.Ramadhani) 


\begin{tabular}{cccc}
\hline 10 & $\sqrt{ }$ & $\sqrt{ }$ & $20 \mathrm{~cm}$ \\
\hline & Total jarak & & $220 \mathrm{~cm}$ \\
\hline
\end{tabular}

Persentase tingkat keberhasilan robot mendekat ke halogen adalah :

Persentase keberhasilan $=\frac{\text { Robot mendehat ke halogen }}{\text { jumlah pengujian }} X 100 \%$

$$
=\frac{8}{10} \times 100 \%=80 \%
$$

Rata-rata jarak robot mendekat ke halogen dengan titik tengah adalah :

$$
\begin{aligned}
\text { Rerata jarak } & =\frac{\text { Total jarak }}{\text { jumiah keberhasilan robot mendekat ke halogen }} \\
& =\frac{220 \mathrm{~cm}}{8}=27.5 \mathrm{~cm}
\end{aligned}
$$

Jadi persentase keberhasilan robot dapat mendekat ke halogen ketika mendeteksi cahaya lampu halogen adalah $80 \%$. Sedangkan rata-rata jarak robot mendekati lampu halogen dengan titik tengah media ukur adalah $27.5 \mathrm{~cm}$.

Berdasarkan persentase keberhasilan robot mendekat ke halogen tersebut dapat disimpulkan bahwa semakin besar nilai persentase keberhasilan yang didapat maka semakin baik robot dapat melaksanakan misi navigasi otomatis mendekati lampu halogen. Sedangkan berdasarkan nilai ratarata jarak robot mendekati lampu halogen dengan titik tengah media ukur dapat disimpulkan bahwa semakin pendek jarak yang dihasilkan maka semakin akurat robot bernavigasi mendekati titik tengah lampu halogen.

\subsection{Pengujian Siang Hari}

Pada pengujian ini terlebih dahulu diukur intensitas cahaya pada area sekitar lapngan pengujian. Hasil pengujian sistem navigasi berbasis mesin visi mendekati cahaya lampu halogen

\begin{tabular}{|c|c|c|c|c|}
\hline Uji Ke- & $\begin{array}{c}\text { Intensitas } \\
\text { Cahaya }\end{array}$ & $\begin{array}{l}\text { Deteksi } \\
\text { Halogen }\end{array}$ & $\begin{array}{l}\text { Mendekat ke } \\
\text { Halogen }\end{array}$ & $\begin{array}{c}\text { Jarak dengan titik } \\
\text { tengah Halogen }\end{array}$ \\
\hline 1 & \multirow{10}{*}{$\begin{array}{l}\text { Rentang nilai } \\
\text { dari Lux meter: }\end{array}$} & $\sqrt{ }$ & $\sqrt{ }$ & $45 \mathrm{~cm}$ \\
\hline 2 & & $\sqrt{ }$ & $\sqrt{ }$ & $45 \mathrm{~cm}$ \\
\hline 3 & & $\sqrt{ }$ & $X$ & - \\
\hline 4 & & $\sqrt{ }$ & $\sqrt{ }$ & $50 \mathrm{~cm}$ \\
\hline 5 & & $\sqrt{ }$ & $\sqrt{ }$ & $45 \mathrm{~cm}$ \\
\hline 6 & & $\sqrt{ }$ & $\sqrt{ }$ & $40 \mathrm{~cm}$ \\
\hline 7 & & $\sqrt{ }$ & $\sqrt{ }$ & $35 \mathrm{~cm}$ \\
\hline 8 & & $X$ & $X$ & - \\
\hline 9 & & $\sqrt{ }$ & $\sqrt{ }$ & $35 \mathrm{~cm}$ \\
\hline 10 & & $\sqrt{ }$ & $X$ & - \\
\hline \multicolumn{4}{|c|}{ Total jarak } & $295 \mathrm{~cm}$ \\
\hline
\end{tabular}
pada siang hari dapat dilihat pada Tabel 6 berikut.

Tabel 6. Pengujian mendekati cahaya lampu halogen pada siang hari

Persentase tingkat keberhasilan robot mendekat ke halogen adalah :

$$
\begin{aligned}
\text { Persentase keberhasilan }= & \frac{\text { Robot mendehat he halogen }}{\text { jumlah pengujian }} X 100 \% \\
& =\frac{7}{10} X 100 \%=70 \%
\end{aligned}
$$

Rata-rata jarak robot mendekat ke halogen dengan titik tengah adalah :

$$
\begin{aligned}
\text { Rerata jorak } & =\frac{\text { Total jarak }}{\text { jumlah heberhasilan robot mendekat ke halogen }} \\
& =\frac{295 \mathrm{~cm}}{7}=42.143 \mathrm{~cm}
\end{aligned}
$$

Jadi ppersentase keberhasilan robot dapat mendekat ke halogen ketika mendeteksi cahaya lampu halogen adalah $70 \%$. Sedangkan rata-rata jarak robot mendekati lampu halogen dengan titik tengah media ukur adalah $42.143 \mathrm{~cm}$.

Berdasarkan persentase keberhasilan robot mendekat ke halogen tersebut dapat disimpulkan 
bahwa semakin besar nilai persentase keberhasilan yang didapat maka semakin baik robot dapat melaksanakan misi navigasi otomatis mendekati lampu halogen. Sedangkan berdasarkan nilai ratarata jarak robot mendekati lampu halogen dengan titik tengah media ukur dapat disimpulkan bahwa semakin pendek jarak yang dihasilkan maka semakin akurat robot bernavigasi mendekati titik tengah lampu halogen. Pengujian navigasi mendekati lampu halogen yang dilakukan pada siang hari tersebut robot mengalami sekali kegagalan dalam mendeteksi cahaya lampu halogen dikarenakan pantulan sinar matahari yang terlalu terik.

\subsection{Pengujian Sore Hari}

Pada pengujian ini terlebih dahulu diukur intensitas cahaya pada area sekitar lapngan pengujian. Hasil pengujian sistem navigasi berbasis mesin visi mendekati cahaya lampu halogen pada sore hari dapat dilihat pada Tabel 7 berikut.

Tabel 7. Pengujian mendekati cahaya lampu halogen pada siang hari

\begin{tabular}{|c|c|c|c|c|}
\hline Uji Ke- & $\begin{array}{l}\text { Intensitas } \\
\text { Cahaya }\end{array}$ & $\begin{array}{l}\text { Deteksi } \\
\text { Halogen }\end{array}$ & $\begin{array}{l}\text { Mendekat ke } \\
\text { Halogen }\end{array}$ & $\begin{array}{c}\text { Jarak dengan titik } \\
\text { tengah Halogen }\end{array}$ \\
\hline 1 & \multirow{2}{*}{$\begin{array}{l}\text { Rentang nilai } \\
\text { dari Lux meter }\end{array}$} & $\sqrt{ }$ & $\sqrt{ }$ & $30 \mathrm{~cm}$ \\
\hline 2 & & $\sqrt{ }$ & $\mathrm{X}$ & - \\
\hline 3 & \multirow{8}{*}{$\begin{array}{l}\text { Minimal : } \\
607 \mathrm{Cd} \\
\text { Maksimal : } \\
18.133 \mathrm{Cd}\end{array}$} & $\sqrt{ }$ & $\sqrt{ }$ & $30 \mathrm{~cm}$ \\
\hline 4 & & $\sqrt{ }$ & $\sqrt{ }$ & $25 \mathrm{~cm}$ \\
\hline 5 & & $\sqrt{ }$ & $\sqrt{ }$ & $15 \mathrm{~cm}$ \\
\hline 6 & & $\sqrt{ }$ & $\sqrt{ }$ & $20 \mathrm{~cm}$ \\
\hline 7 & & $\sqrt{ }$ & $X$ & - \\
\hline 8 & & $\sqrt{ }$ & $\sqrt{ }$ & $25 \mathrm{~cm}$ \\
\hline 9 & & $\sqrt{ }$ & $\sqrt{ }$ & $20 \mathrm{~cm}$ \\
\hline 10 & & $\sqrt{ }$ & $\sqrt{ }$ & $20 \mathrm{~cm}$ \\
\hline \multicolumn{4}{|c|}{ Total jarak } & $185 \mathrm{~cm}$ \\
\hline
\end{tabular}

Persentase tingkat keberhasilan robot mendekat ke halogen adalah :

$$
\begin{aligned}
\text { Persentase keberhasilan }= & \frac{\text { Robot mendekat he halogen }}{\text { jumlah pengujian }} X 100 \% \\
& =\frac{8}{10} \times 100 \%=80 \%
\end{aligned}
$$

Rata-rata jarak robot mendekat ke halogen dengan titik tengah adalah :

$$
\begin{aligned}
\text { Rerata jarak } & =\frac{\text { Total jarak }}{\text { jumlah keberhasilan robot mendekat he halogen }} \\
& =\frac{185 \mathrm{~cm}}{8}=23.125 \mathrm{~cm}
\end{aligned}
$$

Jadi persentase keberhasilan robot dapat mendekat ke halogen ketika mendeteksi cahaya lampu halogen adalah $80 \%$. Sedangkan rata-rata jarak robot mendekati lampu halogen dengan titik tengah media ukur adalah $23.125 \mathrm{~cm}$.

Berdasarkan persentase keberhasilan robot mendekat ke halogen tersebut dapat disimpulkan bahwa semakin besar nilai prosentase keberhasilan yang didapat maka semakin baik robot dapat melaksanakan misi navigasi otomatis mendekati lampu halogen. Sedangkan berdasarkan nilai ratarata jarak robot mendekati lampu halogen dengan titik tengah media ukur dapat disimpulkan bahwa semakin pendek jarak yang dihasilkan maka semakin akurat robot bernavigasi mendekati titik tengah lampu halogen.

\subsection{Pengujian Sore Hari} berikut :

Dari pengujian ketiga waktu yang berbeda tersebut dapat dijadikan rata-rata jarak sebagai

$$
\begin{aligned}
\text { Rata }- \text { rata jarak }= & \frac{(\text { revata jarak pagi }+(\text { rerata jarak siang })+(\text { (rerata jarak sore })}{\text { jumlah wahtu pengujian }} \\
& =\frac{27.5 \mathrm{~cm}+42.143 \mathrm{~cm}+23.125 \mathrm{~cm}}{3}
\end{aligned}
$$




$$
=\frac{92.768 \mathrm{~cm}}{3}=30.923 \mathrm{~cm}
$$

Jadi rata-rata jarak dari pengujian navigasi robot mendekati lampu halogen adalah $30.923 \mathrm{~cm}$ dari titik tengah media ukur.

\subsubsection{Pengujian Landing ke landmark home}

Berbeda dengan pengujian sistem ketika robot mendeteksi cahaya lampu halogen, pada pengujian ini robot dilihat apakah dapat melakukan landing secara otomatis ketika mendeteksi landmark home. Pada pengujian ini tidak memerlukan media ukur khusus.

\subsection{Pengujian Pagi Hari}

Pada pengujian ini terlebih dahulu diukur intensitas cahaya pada area sekitar lapngan pengujian. Hasil pengujian sistem navigasi berbasis mesin visi landing ke landmark home pada pagi hari dapat dilihat pada Tabel 8 berikut.

Tabel 8. Pengujian mendekati cahaya lampu halogen pada pagi hari

\begin{tabular}{|c|c|c|c|}
\hline Uji Ke- & $\begin{array}{c}\text { Intensitas } \\
\text { Cahaya }\end{array}$ & $\begin{array}{c}\text { Deteksi } \\
\text { Landmark home }\end{array}$ & $\begin{array}{c}\text { Landing ke } \\
\text { Home }\end{array}$ \\
\hline 1 & \multirow{10}{*}{$\begin{array}{l}\text { Rentang nilai } \\
\text { dari Lux meter : } \\
\text { Minimal : } 26 \mathrm{Cd} \\
\text { Maksimal : } 9.614 \\
\text { Cd }\end{array}$} & $\sqrt{ }$ & $\sqrt{ }$ \\
\hline 2 & & $\sqrt{ }$ & $X$ \\
\hline 3 & & $\sqrt{ }$ & $\sqrt{ }$ \\
\hline 4 & & $\sqrt{ }$ & $\sqrt{ }$ \\
\hline 5 & & $\sqrt{ }$ & $X$ \\
\hline 6 & & $\sqrt{ }$ & $\sqrt{ }$ \\
\hline 7 & & $\sqrt{ }$ & $\sqrt{ }$ \\
\hline 8 & & $\sqrt{ }$ & $\sqrt{ }$ \\
\hline 9 & & $\sqrt{ }$ & $\sqrt{ }$ \\
\hline 10 & & $\sqrt{ }$ & $X$ \\
\hline
\end{tabular}

Persentase tingkat keberhasilan robot medarat ke Home adalah :

$$
\begin{aligned}
\text { Persentase keberhasilan }= & \frac{\text { Robot mendarat he Home }}{\text { Jumlah pengujian }} \text { X } 100 \% \\
& =\frac{7}{10} \times 100 \%=70 \%
\end{aligned}
$$

Jadi persentase keberhasilan robot dapat landing ke Home adalah $70 \%$. Berdasarkan persentase keberhasilan robot landing ke Home tersebut dapat disimpulkan bahwa semakin besar nilai prosentase keberhasilan yang didapat maka semakin baik robot dapat melaksanakan misi navigasi landing secara otomatis

\subsection{Pengujian Siang Hari}

Pada pengujian ini terlebih dahulu diukur intensitas cahaya pada area sekitar lapngan

\begin{tabular}{|c|c|c|c|}
\hline Uji Ke- & $\begin{array}{c}\text { Intensitas } \\
\text { Cahaya }\end{array}$ & $\begin{array}{c}\text { Deteksi } \\
\text { Landmark home }\end{array}$ & $\begin{array}{c}\text { Landing ke } \\
\text { Home }\end{array}$ \\
\hline 1 & \multirow{10}{*}{$\begin{array}{l}\text { Minimal : } 15.548 \\
\text { Cd } \\
\text { Maksimal : } \\
26.349 \mathrm{Cd}\end{array}$} & $\sqrt{ }$ & $\sqrt{ }$ \\
\hline 2 & & $\sqrt{ }$ & $\sqrt{ }$ \\
\hline 3 & & $\sqrt{ }$ & $X$ \\
\hline 4 & & $\sqrt{ }$ & $\sqrt{ }$ \\
\hline 5 & & $\sqrt{ }$ & $\sqrt{ }$ \\
\hline 6 & & $\sqrt{ }$ & $\sqrt{ }$ \\
\hline 7 & & $\sqrt{ }$ & $\mathrm{X}$ \\
\hline 8 & & $\sqrt{ }$ & $\mathrm{X}$ \\
\hline 9 & & $\sqrt{ }$ & $\sqrt{ }$ \\
\hline 10 & & $\sqrt{ }$ & $\mathrm{X}$ \\
\hline
\end{tabular}
pengujian. Hasil pengujian sistem navigasi berbasis mesin visi landing ke landmark home pada siang hari dapat dilihat pada Tabel 9 berikut. 
Persentase tingkat keberhasilan robot landing ke Home adalah :

$$
\begin{aligned}
\text { Persentase keberhasilan }= & \frac{\text { Robot mendarat he Home }}{\text { jumlah pengujian }} X 100 \% \\
& =\frac{6}{10} X 100 \%=60 \%
\end{aligned}
$$

Jadi persentase keberhasilan robot dapat landing ke Home adalah 60\%. Berdasarkan persentase keberhasilan robot landing ke Home tersebut dapat disimpulkan bahwa semakin besar nilai prosentase keberhasilan yang didapat maka semakin baik robot dapat melaksanakan misi navigasi landing secara otomatis

\subsection{Pengujian Sore Hari}

Pada pengujian ini terlebih dahulu diukur intensitas cahaya pada area sekitar lapngan pengujian. Hasil pengujian sistem navigasi berbasis mesin visi landing ke landmark home pada sore

\begin{tabular}{|c|c|c|c|}
\hline Uji Ke- & $\begin{array}{c}\text { Intensitas } \\
\text { Cahaya }\end{array}$ & $\begin{array}{c}\text { Deteksi } \\
\text { Landmark home }\end{array}$ & $\begin{array}{c}\text { Landing ke } \\
\text { Home }\end{array}$ \\
\hline 1 & \multirow{5}{*}{$\begin{array}{l}\text { Rentang nilai } \\
\text { dari Lux meter: }\end{array}$} & $\sqrt{ }$ & $\sqrt{ }$ \\
\hline 2 & & $\sqrt{ }$ & $X$ \\
\hline 3 & & $\sqrt{ }$ & $\sqrt{ }$ \\
\hline 4 & & $\sqrt{ }$ & $\sqrt{ }$ \\
\hline 5 & & $\sqrt{ }$ & $\sqrt{ }$ \\
\hline 6 & \multirow{5}{*}{$\begin{array}{l}\text { Minimal : } 607 \\
\text { Cd } \\
\text { Maksimal : } \\
18.133 \mathrm{Cd}\end{array}$} & $\sqrt{ }$ & $\sqrt{ }$ \\
\hline 7 & & $\sqrt{ }$ & $X$ \\
\hline 8 & & $\sqrt{ }$ & $\sqrt{ }$ \\
\hline 9 & & $\sqrt{ }$ & $\sqrt{ }$ \\
\hline 10 & & $\sqrt{ }$ & $\sqrt{ }$ \\
\hline
\end{tabular}
hari dapat dilihat pada Tabel 10 berikut.

Persentase tingkat keberhasilan robot landing ke Home adalah :

$$
\begin{aligned}
\text { Persentase keberhasilan }= & \frac{\text { Robot mendarat ke Home }}{\text { jumlah pengujian }} \times 100 \% \\
= & \frac{8}{10} \times 100 \%=80 \%
\end{aligned}
$$

Jadi persentase keberhasilan robot landing ke Home adalah $80 \%$. Berdasarkan persentase keberhasilan robot landing ke Home tersebut dapat disimpulkan bahwa semakin besar nilai prosentase keberhasilan yang didapat maka semakin baik robot dapat melaksanakan misi navigasi landing secara otomatis.

\subsection{Pengujian Sore Hari}

Dari pengujian ketiga waktu yang berbeda tersebut dapat dijadikan rata-rata persentase keberhasilan landing ke Home sebagai berikut :

$$
\begin{aligned}
\text { Rata-rata jarak } & =\frac{(\text { rerata jarakpagi })+(\text { nerata jarak siang })+(\text { rerata jaraksore })}{\text { Jumlah waktupengujian }} \\
& =\frac{70 \%+60 \%+80 \%}{3} \\
& =\frac{210 \%}{3}=70 \%
\end{aligned}
$$

Jadi rata-rata persentase keberhasilan dari pengujian robot landing ke Home adalah $70 \%$.

\section{Kesimpulan}

Berdasarkan hasil penelitian dan pengujian sistem mesin visi yang telah dilakukan, maka dapat disimpulkan sebagai berikut :

1. Persentase ketahanan dalam kesalahan deteksi objek lingkaran warna merah, hitam dan biru pada deteksi cahya lampu halogen adalah $100 \%$. 
2. Persentase ketahanan dalam kesalahan deteksi objek persegi warna merah dan biru pada deteksi landmark home adalah $100 \%$.

3. Persentase ketahanan dalam kesalahan deteksi objek persegi warna coklat pada deteksi landmark home adalah $80 \%$.

1) Berdasarkan hasil pengujian navigasi robot ketika mendekati cahaya lampu halogen dan landing ke home adalah sebagai berikut :

1. Rata-rata jarak robot mendekati lampu halogen berbasis GPS dari titik tengah media ukur adalah $86.5 \mathrm{~cm}$, sedangkan rata-rata jarak robot dengan berbasis GPS dan mesin visi pada ketiga waktu pengujian adalah $30.923 \mathrm{~cm}$.

2. Persentase keberhasilan robot dapat landing ke Home berbasis GPS adalah 10\%, sedangkan persentase keberhasilan robot dengan berbasis GPS dan mesin visi pada ketiga waktu pengujian adalah $70 \%$.

Hasil yang didapatkan dari pergerakan robot dengan sistem berbasis GPS dan mesin visi untuk mendekati cahaya lampu halogen dan melakukan landing di dalam zona landmark home adalah robot dapat bernavigasi lebih akurat dibandingkan dengan navigasi robot menggunakan panduan GPS secara penuh.

\section{Referensi}

[1] Munir, Rinaldi. (2006). Aplikasi Image Thresholding Untuk Segmentasi Objek. Seminar Nasional Aplikasi Teknologi Informasi, Yogyakarta.

[2] Ahrens, S., Levine, D., Andrew, G. \& How, J.P. (2009). Vision-Based Guidance and Control of a Hovering Vehicle in Unknown, GPS-Deined Environments. Japan : International Conference on Robotic and Automation.

[3] Sutoyo, T, Edy mulyanto, Vincen Suhartono, Oky Dwi Nurhayat, Wijanarto, (2009), Teori Pengolahan Citra Digital, CV.Andi Offset, Yogyakarta.

[4] Eberli, D., Scaramuzza, D., Weiss, S. \& Seigwart, R. (2010). Vision Based Position Control for MAVs Using One Single Circular Landmark. Switzerland: ETH Autonomous Systems Laboratory.

[5] Huaman, A., (2012). OpenCV Reference Manual, disadur dari www.opencv.org/download/manual/OpenCV_Manual.pdf, (diakses pada 11 September 2015)

[6] Carrilo, L.R.G., Lopez, A.E.D., Lozano, R. \& Pegard, C. (2013). Quad Rotorcraft Control, Vision-Based Hovering and Navigation. London: Advances in Industrial Control.

[7] Bachtiar, Mohammad Mobed. (2014). Simulasi Penentuan Posisi 3D Quadcopter Berbasis Enhancement Particle Filter Using Antcolony Optimization. Indonesia: Indonesian Symposium on Robot Soccer Competition 2014.

[8] Fahmizal, (2014). Dasar-Dasar Quadcopter, disadur dari www.fahmizaleeits.wordpress.com/category/robotika/, (diakses pada 22 Desember 2015)

[9] Kurnianto, Danny. (2015). Pengolahan Citra Digital. Disadur dari https://catatanpeneliti.wordpress.com/category/pengolahan-citra-digital/ (Diakses tanggal 7 Desember 2015)

[10] Direktorat Jendral Pendidikan Tinggi. Buku Panduan KRTI (Kontes Robot Terbang Indonesia) 2015 v.24-8-2015, Jakarta.

[11] GPS Ublox NEO 7M, disadur dari www.lapantech.com/jual-GPS-Ublox-NEO-7M-pixhawkardupilot-APM-quadcopter-presisi-surabaya/, (diakses pada 11 September 2015)

[12] ESC SunnySky 40A, disadur dari www.banggood.com/Hobbywing-XRotor-40A-APAC-BrushlessESC-2-6S-For-RC-Multicopters-p-947342.html, (diakses pada 22 Desember 2015)

[13] Odroid XU-3, disadur dari www.hardkernel.com/main/products/prdt_info.php?g_code=g138745696275, (diakses pada 22 Desember 2015)

[14] Pixhawk Flight Controller, disadur dari www.bhphotovideo.com/c/product/1098160REG/3d_robotics_px4_kit_0011_pixhawk_32_bit_aut opilot_system.htm, (diakses pada 22 Desember 2015)

[15] Logitech Webcam, disadur dari www.eventus.si/en/cameras/i_370_logitech-portable-webcamc905-usb, (diakses pada 22 Desember 2015)

[16] Radio Telemetry $433 \mathrm{Mhz}$, disadur dari www.buaya-instrument.com/fpv-radio-telemetry-kit433mhz-fpv433.html?search=telemetry, (diakses pada 5 Januari 2016)

[17] Linux, disadur dari www.id.wikipedia.org/wiki/Linux, (diakses pada 20 Maret 2016)

[18] Ultra VNC, disadur dari www.de.wikipedia.org/wiki/UltraVNC, (diakses pada 12 Juni 2016) 
Jurnal IImu Teknik Elektro Komputer dan Informatika (JITEKI)

Vol. 2, No. 2, Desember 2016

[19] Mission Planner Overview, disadur dari www.ardupilot.org/planner/docs/mission-planneroverview.html, (diakses pada 12 Juni 2016)

[20] DroneKit-Python's Documentation, www.python.dronekit.io/, (diakses pada 12 Juni 2016)

[21] Gens Ace 5300MAH 11.1V, disadur dari www.surabayahobby.com/produk_2951_gens-ace5300mah-11-1v-30c-3s1p-lipo-battery-pack.html, (diakses pada 12 Juni 2016) 